Bangladesh J. Plant Taxon. 19(2): 109-117, 2012 (December)

(C) 2012 Bangladesh Association of Plant Taxonomists

\title{
MORPHOLOGY OF OVULE, SEED AND POLLEN GRAIN OF RAFFLESIA R. BR. (RAFFLESIACEAE)
}

\author{
Nery Sofiyanti ${ }^{1}$ And ChoOng Chee Yen ${ }^{2}$ \\ Department of Biology, Faculty of Mathematics and Natural Sciences, University of Riau, Kampus \\ Bina Widya Panam, Pekanbaru, Riau, Indonesia
}

Keywords: Rafflesia; Ovule; Seed; Pollen grain.

\begin{abstract}
The ovules, seeds and pollen grains of 24 Rafflesia specimens from nine species were examined. The ovules and seeds of all specimens showed similar shapes and structures. Rafflesia ovules are J-shaped and incompletely anatropous, while the seeds are chestnut-shaped. The pollen grains are small (10-25 $\mu \mathrm{m}$ in diameter), prolate-spheroidal and subprolate, monoporate, with a smooth surface and no ornamentation.
\end{abstract}

\section{Introduction}

Rafflesia R. Br. is a parasitic genus comprising 33 species (summarized from Nais, 2001; Susatya et al., 2006; Mat-Salleh et al., 2010; Wiriadinata, 2010; Barcelona et al., 2011). This genus grows in limited localities in the tropical rainforest of Southeast Asia (Wong, 1992; Hidayati et al., 2000; Balete et al., 2010; Barcelona et al., 2011) including Sumatera, Java, Borneo, Peninsular Malaysia, Southern Thailand and the Philippines (Barcelona et al., 2006, 2007; Ghazally et al., 1988). As a holoparasitic plant, no members of Rafflesia have vegetative part, the only visible part is the reproductive part that emerges from its specific host, Tetrastigma (Vitaceae) (Meijer, 1997; Nais, 2001). Rafflesia is characterized by five perigone lobes which are orange to reddish in colour (Nais, 2001) and thought to mimic rotting flesh flower (Barkman et al., 2008).

Since the discovery of first species in Bengkulu, Sumatera (Brown, 1821), Rafflesia has astounded the scientific community and caused a sensation in the botanical world (Banzinger, 1991). This genus includes the largest flower in the world, and according to Barkman et al. (2008) the flower diameter of Rafflesia is 10 to 100 times larger than those of most other flowering plant genera. This plant with gigantic flower has fascinated and baffled researchers, and become a public interest.

As other Rafflesiaceae genera, the flowers of Rafflesia are very rare (Banzinger, 2004). Some reasons for their rarity are: 1 . The parasitic way of life, it needs a specific host (Tetrastigma); 2. most of the species are dioecious (male and female flowers do not usually simultaneously bloom); 3. imbalanced sex ratio (the overall male and female flower ratio is $7: 1$ ); 4 . fruit set percentage among female is low, 35.71\% (Nais and Wilcock, 1998); 5. high bud mortality, 40$91 \%$ in some cases up to $100 \%$ (Nais, 2001) and 6. long life cycle up to five years from seed to seed in Rafflesia arnoldii (Meijer, 1997). Therefore, the biology of Rafflesia remains largely unknown.

The study of ovule, seed and pollen morphology is limited in Rafflesia. Very few studies had been conducted on micromorphological aspects (Brown, 1834; Olah, 1960; Takhtajan et al., 1985; Bouman and Meijer, 1994). Most of these studies deal with a single or few species only. Here, we describe the morphology of the ovules, seeds and pollen grains of nine species of Rafflesia from

\footnotetext{
${ }^{1}$ Corresponding author. Email: nery_yusuf@yahoo.com

${ }^{2}$ School of Environmental and Natural Resource Sciences, Faculty of Science and Technology, National University of Malaysia, Bangi Selangor 43600, Malaysia
} 
Pahang, Perak (Peninsular Malaysia), Sabah (East Malaysia), North Sumatera, Bengkulu and Riau (Indonesia).

\section{Materials and Methods}

Table 1 shows the materials examined in this study. This small sample size is due to the rarity of Rafflesia. Moreover, studying micromorphology of this genus is very destructive. All materials were observed using a Scanning Electron Microscope (SEM). The specimens were fixatived in $2.5 \%$ glutaraldehyde, followed by a series of ethanol dehydration. A Critical Point Drier 7501 was used to dry the dehydrated tissues. The samples were then sputter-coated with gold-palladium for 5 minutes using Thermo UG Scientific Polaron.

The measurement and morphological observations were made with a Phillips XL 30 microscope, based on 20 samples per specimen to perform statistical analyses. For ovules and seeds, we measured the following: microphyle diameter (MD), micropylar part length (MPL), micropylar part width (MPW), funiculus width (FW), funiculus length (FL), raphal width (RW), and raphal length (RL). Some pollen grains were also observed using light microscope (LM) Meiji MX microscope assisted with Olympus E 330 camera in unstained glycerin jelly. The terminology of pollen used in this study is based on Ertdman (1972).

\section{Results and Discussion Ovules and seeds}

The ovules and seeds of all specimens examined (Fig. 1) have similar shapes and structure but differ in their sizes. Therefore, due to this morphological homogeneity, the descriptions of ovules and seeds given below are based on the summary of all specimens examined, while detailed measurements are presented in Table 2.

\section{Description of ovule}

White when fresh, J-shaped and irregularly attached to the placenta. Placenta has a polygonal cell wall. The structure can be divided into three parts, the funiculus, raphal and microphylar parts. Funiculus: Cross-section is rose-shaped, has rudimentary cells at outer integument; Raphal part: Irregularly shaped, rudimentary cells at outer integument, located at the middle part of ovule, no clear distinction with funiculus. Micropylar part: Outer wall presents irregular rows, the width is almost the same from tip to base, the tip is donut-shaped.

Bouman and Meijer (1994) indicated that species with wider flower diameter usually have bigger ovules. Fig. 1 presents the SEM photographs of ovules of R. azlanii (Fig. 1A-C), R. kerrii (Fig. 1D-E), R. hasseltii (Fig. 1F), R. cantleyi (Fig. 1G), and R. tuan-mudae (Fig. 1H-J). In this study, $R$. kerrii had the biggest flower while $R$. tuan-mudae had the smallest flower among the taxa examined. According to Meijer (1997) and Nais (2001) the open flower diameter of R. kerrii ranges from 50 to $70 \mathrm{~cm}$. Mat Ros (pers. comm.) recorded the widest flower of $R$. kerrii from Peninsular Malaysia, up to $111 \mathrm{~cm}$. However, the ovule of $R$. kerrii examined in this study was smaller than $R$. azlanii, $R$. hasseltii and $R$. cantleyi as presented in Table 2 . This may be due to the ovule of $R$. kerrii used in this study was collected from female bud, and hence the size was smaller because the ovule is not yet well-developed. The probably size of the matured ovules should be greater than ovules of $R$. cantleyi examined in this study. The flower diameter of $R$. tuan-mudae according to Nais (2001) is $26-33 \mathrm{~cm}$, smaller than $R$. hasseltii, $R$. cantleyi and $R$. azlani. Its ovules are also smaller than these three species. But surprisingly, the microphyle diameter of $R$. tuan-mudae (Fig. 1I) is the widest among the species examined (46.22 $\pm 04.01 \mu \mathrm{m})$ and quite unique. 


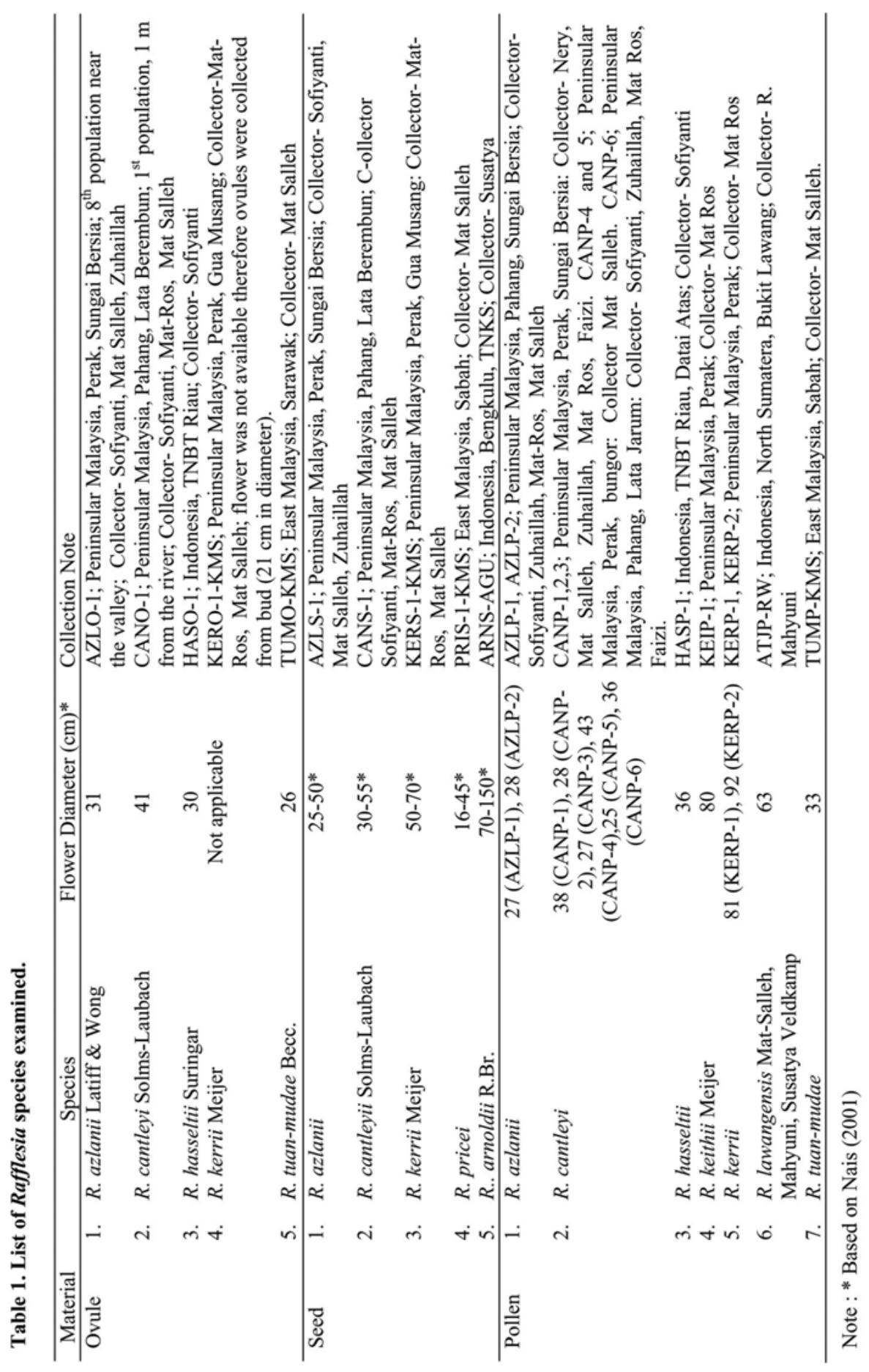




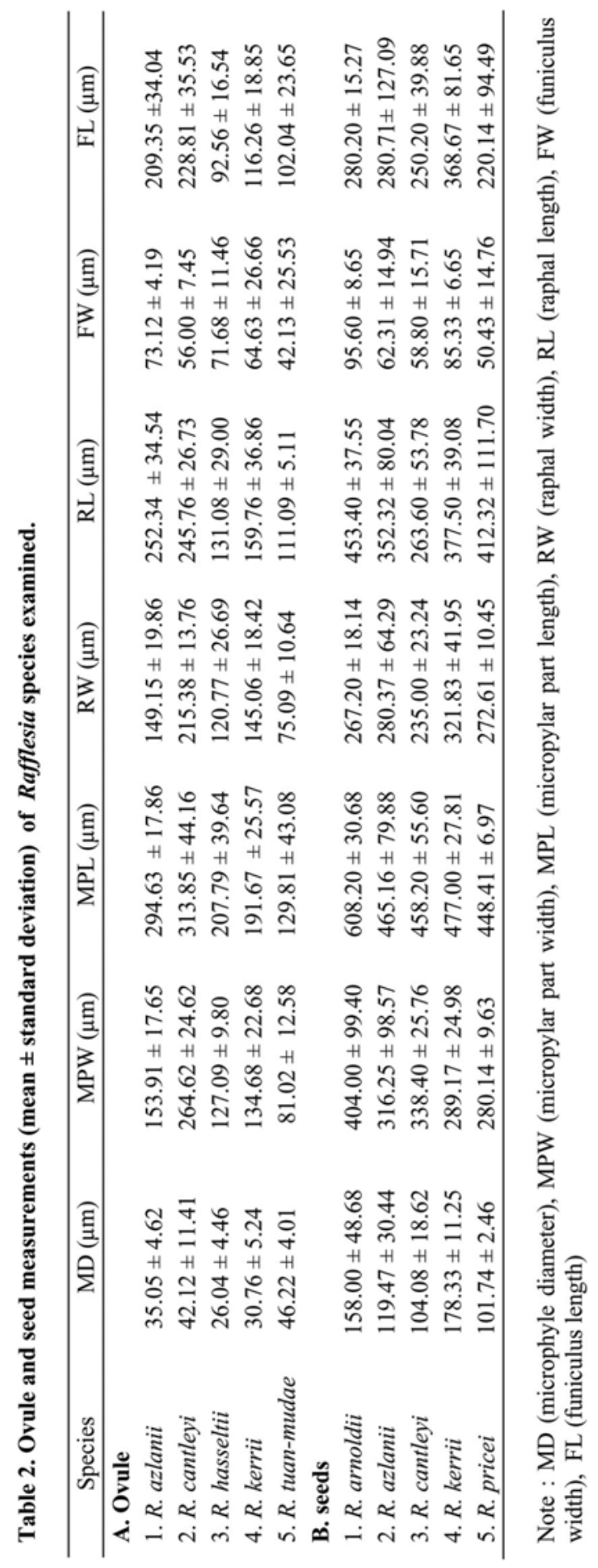




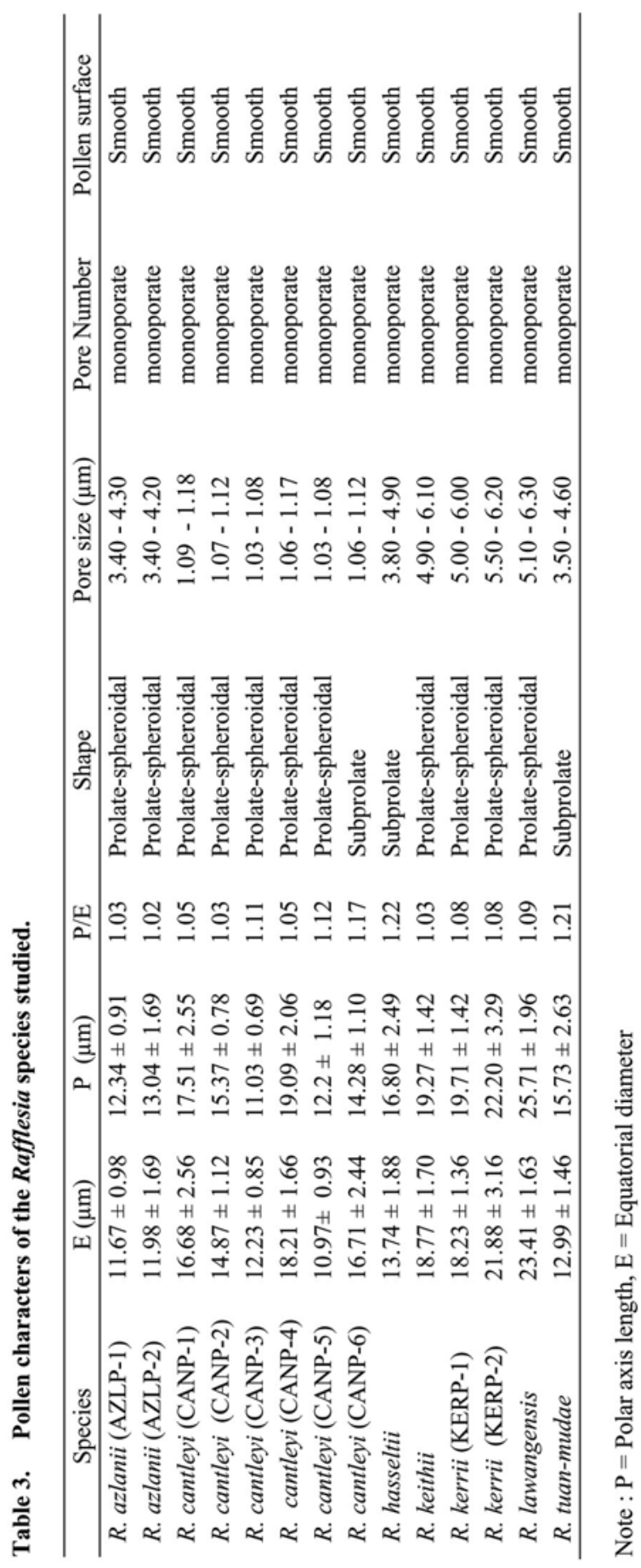



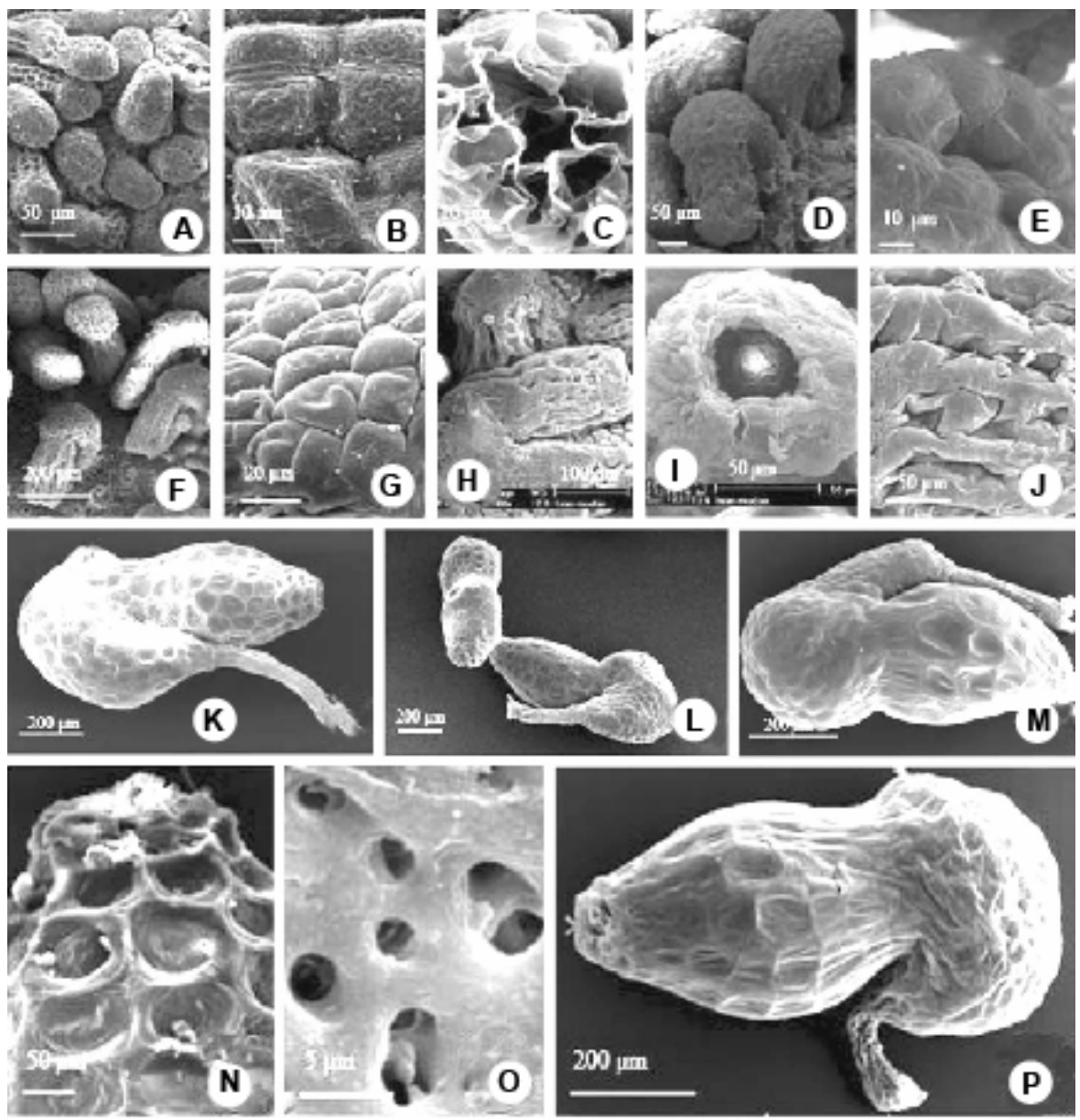

Fig. 1. SEM photographs of Rafflesia ovules (A-J) and seeds (K-P ). A - C. R. azlanii, B. Outer integument, C. cross section of funiculus, D-E. R. kerrii, E. microphyle, F. $R$. hasseltii, G. placenta wall of $R$. cantleyi, H-J. R. tuan-mudae, I. microphyle, J. outer integument of microphylar part, K. R. azlanii, L. $R$. kerrii, M. R. pricei, N-O. R. arnoldii, N. microphylar part, O. inner integument with pores, P. $R$. cantleyi.

Rafflesia has an incomplete anatropous ovules with the microphyle facing downward and situated near the base of funiculus, but the apical part is not bound to the raphe. Sometimes the distinction between raphal and funiculus is not clear, because the funiculus of ovule was not well developed, and its width was almost the same as raphal width. The placenta of Rafflesia consisted of polygonal cell walls (as seen in Fig. 1G). The cross-section of the funiculus showed the empty cell (Fig. 1C). The ovules of all the species studied here were unitegmic. This result was in accordance to that of Bouman and Meijer (1994), who observed the same type of ovules in all the genera of Rafflesiaceae (Rafflesia, Rhizanthes and Sapria). According to Takhtajan (2009), the unitegmic ovule could have resulted from the congenital fusion of inner and outer integuments or due to the abortion of one of the integuments. The embryo sac of Rafflesia is a monosporic type as the single surviving megaspore undergoes three rounds of mitotic nuclear division without any wall formation. The type of embryo sac of Rafflesia is Polygonum type, which is found in $81 \%$ of the Angiospermae (Mauseth, 1988). 
Rafflesia seeds are usually chestnut-shaped, brown when fresh. The funiculus shows a different outer integument from raphal and micropylar part. This part can be easily distinguished from the raphal part. Raphal part has a curvature, unequal shape and swollen at the middle. The micropylar part is located near the funiculus due to the curvature of raphal part, the middle portion has the largest integument cell, whereas the rounded microphyle is located on the tip. The outer integument is reduced, visible only as a broad, insignificant rim proximal to the base of the inner integument and consists of polygonal cell wall. The inner integument is U-shaped in cross section and has many pores as seen in R. arnoldii seed (Fig. 1O). Figure $1 \mathrm{~K}-\mathrm{P}$ present the seeds of all species studied, while Table 2 shows the measurements of the different seed parts. The highest values of total measurement were observed in $R$. arnoldii. This species is known as the widest flower in the world (Nais, 2001) with open flower diameter ranging at 70-150 cm.
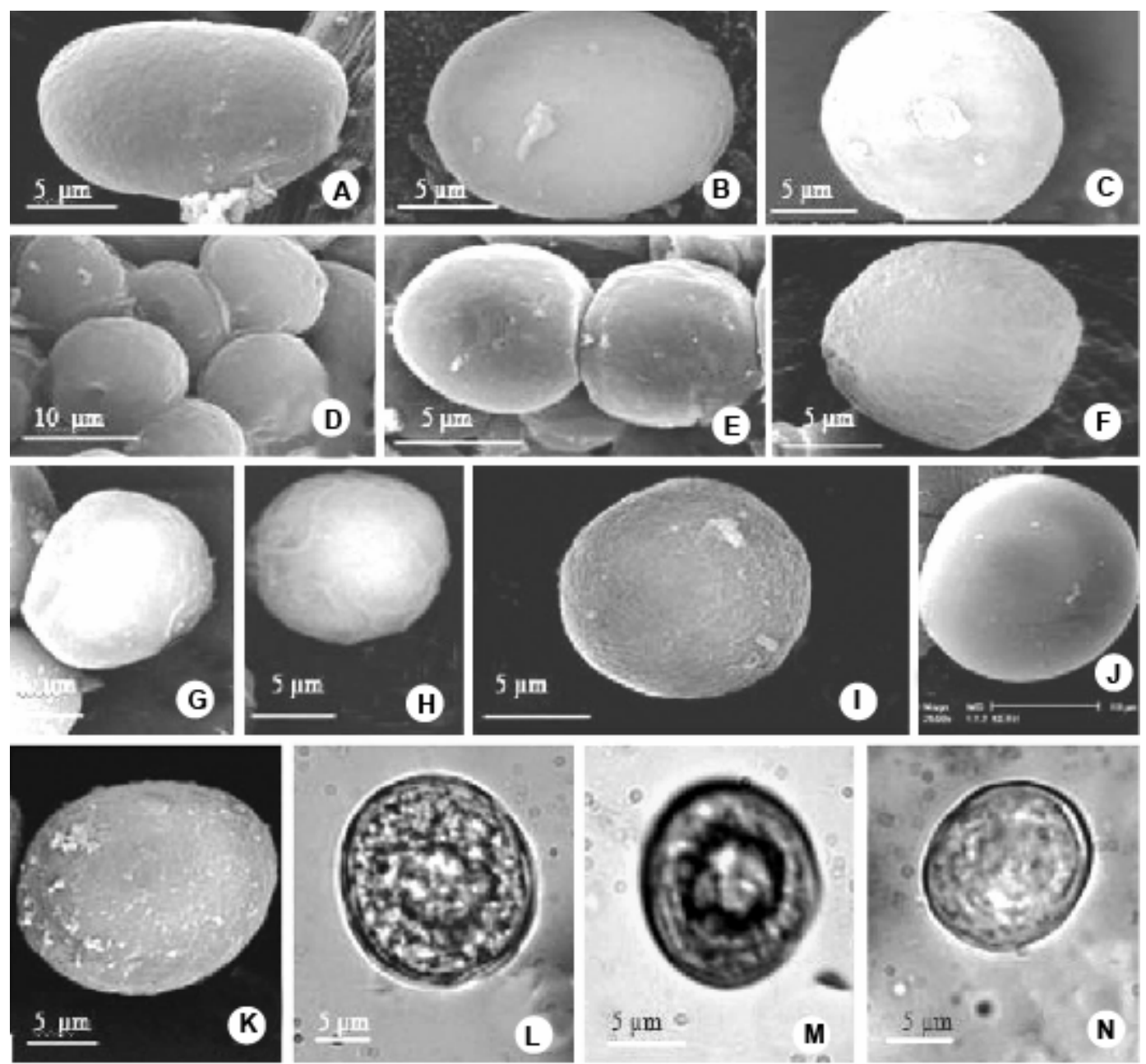

Fig. 2. SEM (A-K) and LM (L-N) photographs of Rafflesia pollen grains. A. R. tuan-mudae, B. R. hasseltii, C. and D. $R$. azlanii (C. AZLP-1, D. AZLP-2), E-I. R. cantleyi (E. CANP-1, F. CANP-2, G. CANP-3, H. CANP-4, I. CANP-6), J. R. keithii, K. R. kerrii (KERP-1), L. R. lawangensis, M and N. R.cantleyi (CANP-5). 


\section{Pollen}

Rafflesia pollen is not released as a single grain, but adhered to each other due to a sticky yellow mush. SEM and LM photographs of pollen are shown in Fig. 2. The pollen grains of all species observed in this study have one pore (monoporate pollen) and a smooth surface without ornamentation. However, two distinct shapes were observed, subprolate and prolate-spheroidal. Subprolate shape is describing the shape of a pollen grain in which the ratio between the polar axis and the equatorial diameter ( $\mathrm{P} / \mathrm{E}$ ratio) is 1.14-1.33, while prolate-spheroidal shape has $\mathrm{P} / \mathrm{E}$ ratio ranging from 1.00 to 1.14 (Erdmant, 1972). Subprolate pollen was found in R. tuan-mudae (Fig. 2A), $R$. hasseltii (Fig. 2B), and one R. cantleyii specimen (CAN 6). But the common shape is prolate-spheroidal, which is found in $R$. azlanii (Fig. 2C and D), R. cantleyi (CAN 1-5) (Fig. 2E$\mathrm{H}$ and $\mathrm{M}-\mathrm{N}$ ), R. keithii (Fig. 2J), R. kerii (Fig. 2K) and R. lawangensis (Fig. 2L). Prolatespheroidal pollen grains in this study have $\mathrm{P} / \mathrm{E}$ ratio ranging from 1.02 to 1.12, and the P/E ratio for subprolate is from 1.17 to 1.22 . Usually species with wider flower diameter has bigger pollen grains, however in this study we find an interesting result, $R$. lawangensis from North Sumatera (Indonesia) shows the bigger pollen size than $R$. keithii and $R$. kerrii eventhough its flower diameter is smaller $(63 \mathrm{~cm})$ than both species (Table 1).

\section{Acknowledgements}

The authors are grateful to the late Prof. Dr. Kamarudin Mat-Salleh; Minister of Forestry, Indonesia; Rafflesia team members UKM Malaysia (Mat Ros, Nor Zuhaillah, Agus Susatya, Donna Jackson, Ridha Mahyuni, Siti Munirah, M. Faizi, Jessica, Jazreen, Mira, Khairul, Tan Ai lee, Nida). This study was funded by TPSDP (DIKTI Indonesia); Malaysian Government Research Grant (IRPA Grant No 09-02-02-0035EA131 led by the late Prof. Mat-Salleh). Many thank to International Association of Plant Taxonomy (IAPT, Vienna) for providing a field trip research grant in 2006.

\section{References}

Balete, D.S., Pelser, P.B., Nickrent, D.L. and Barcelona, J.F. 2010. Rafflesia verrucosa (Rafflesiaceae), a new species of small-flowered Rafflesia from eastern Mindanao, Philippines. Phytotaxa 10: 49-57.

Banzinger, H. 1991. Stench and fragrance: unique pollination lure of Thailand's largest flower, Rafflesia kerrii Meijer. Natural History Bulletin of Siam Society 39: 19-52.

Banzinger, H. 2004. Studies on hitherto unknown fruits and seeds of some Rafflesiaceae, and a method to manually pollinate their flowers for research and conservation. Linzer Biology Beitr 36(2): 1175-1198.

Barcelona, J.F., Cajano, M.O. and Hadsall., A.S. 2006. Rafflesia baletei, another new Rafflesia (Rafflesiaceae) from the Philippines. Kew Bull. 61(2): 231-237

Barcelona, J.F., Pelser, P.B. and Cajano, M.O.. 2007. Rafflesia banahaw (Rafflesiaceae), a new species from Luzon, Philippines. Blumea 52: 345-350

Barcelona, J.F., Fernando, E.S., Nickrent, D.D., Balete, D.S. and Pelser, P.B. 2011. An amended description of Rafflesia leonardi and a revised key to Philippine Rafflesia (Rafflesiaceae). Pytotaxa 24: 11-18.

Barkman, T.J., Bendiksby, A.M., Lim, S.H., Mat-Salleh, K., Nais, J., Madulid, and Schumacher, T. 2008. Accelerated rates of floral evolution at the upper size limit for flower. Current Biology 18: 1508-1513.

Bouman, F. and Meijer, W. 1994. Comparative structure of ovules and seeds in Rafflesiaceae. Plant Systematics and Evolution 193: 187-212.

Brown, R. 1821. An account of a new genus of plant named Rafflesia. Transaction of the Linnean Society of London 13: 201-234.

Brown, R. 1834. Description of the female flower and fruit of Rafflesia arnoldii, with remarks on its affinities and an illustration of the structure of Hydnora africana. Transaction of the Linnean Society of London 19: 221-238. 
Erdtman, G. 1972. Pollen Morphology and Plant Taxonomy. New York: Hafner Pub. Com.

Ghazally, I., Mat-Salleh, K., Ali, L. and Adlin, T.D.Z. 1988. Rafflesia of Sabah: A case for conservation. Sabah Society Journal 9: 437-456.

Hidayati, S.N., Meijer, W., Baskin, J.M. and Waick, J.L. 2000. A contribution to the life history of the rare Indonesian holoparasite Rafflesia patma (Rafflesiaceae). Biotropica 32(3): 408-414.

Mat-Salleh, K., Mahyuni., R., Susatya, A. and Veldkamp, F. 2010. Rafflesia lawangensis (Rafflesiaceae), a new species from Bukit Lawang, Gunung Leuser National Park, North Sumatra, Indonesia. Reinwardtia 13(2): 159-165

Mauseth, J.D. 1988. Plant Anatomy. California: The Benjamin/Cummings Publishing Company, Inc.

Meijer, W. 1997. Rafflesiaceae. Flora Malesiana 13: 1-42.

Nais, J. 2001. Rafflesia of the World. Kota Kinabalu: Natural History Publications.

Nais, J. and Wilcock, C.C. 1998. The Rafflesia conservation incentive scheme in Sabah, Malaysian Borneo. Sabah Parks Nature Journal 2: 111-120.

Olah, L.V. 1960. Cytological and morphological investigations in Rafflesia arnoldii. Bulletin of the Torrey Botanical Club 87(6): 406-416.

Susatya, A., Arianto, W. and Mat-Salleh, K. 2006. Rafflesia bengkuluensis (Rafflesiaceae), a new species from south Sumatera, Indonesia. Folia Malaysiana 6: 139-152.46

Takhtajan, A.J., Meyer, N. and Kocenko, V.N. 1985. Pollen morphology and classification in Rafflesiaceae. Botahniecknn Kyphan 2: 153-164.

Takhtajan, A.J. 2009. Flowering Plants. Springer Verlag.

Wiriadinata, H. 2010. A new species of Rafflesia from North Sumatera. Reinwardtia 13(2): 95-100.

Wong, M. 1992. Kerr's Rafflesia: a rare botanical gem. Nature Malaysiana 17(4): 124-125.

(Manuscript received on 1 March 2012; revised on 18 October 2012) 